\title{
RECENZJE
}

\section{SŁAWOMIR KuRSA, Testator i formy testamentu w rzymskim prawie justyniańskim, wyd. Wolters Kluwer Polska, Warszawa 2017, ISBN 978-83-8107-366-0, ss. 352}

Monografia Sławomira Kursy dotycząca testatora i form testamentu w prawie justyniańskim stanowi próbę kompleksowego przedstawienia tytułowych zagadnień. Podjęta tematyka zapowiada pozycję ciekawą na polskim rynku - wśród problematyki poruszanej przez polskich romanistów wciąż niewiele jest opracowań dotyczących prawa poklasycznego.

Książka składa się ze wstępu i ośmiu podzielonych na mniejsze jednostki redakcyjne rozdziałów. Wieńczy ją zakończenie, a uzupełnia indeks źródeł (podzielony dla wygody na źródła prawne, pozaprawne i papirologiczne) oraz wykaz literatury.

We wstępie autor precyzuje stawiane sobie cele i opisuje problemy badawcze, których rozwiązanie zaplanował. Postawił także dwie wykluczające się hipotezy (a właściwie tezy) badawcze, mianowicie: „w prawie justyniańskim wartość swobody testowania była wyżej ceniona niż bezpieczeństwo obrotu prawnego w zakresie testamentów” oraz „w prawie tym możemy mówić o zrównoważonym traktowaniu wymienionych wartości” (s. 14).

Rozdział I, zatytułowany „Problemy terminologiczne i dogmatyczne testamentu w prawie justyniańskim”, zawiera podrozdziały związane z etymologicznym i dogmatycznym wyjaśnieniem terminu „testament”, a także fragment dotyczący zgodności definicji doktrynalnych z definicją legalną testamentu w prawie justyniańskim.

Rozdział II nosi tytuł „Zarys figury prawnej testatora w ujęciu źródeł prawa justyniańskiego". Podzielony jest na dwie główne części. Wyjaśnione jest w nim znaczenie terminu testamenti factio activa (po kolei 
omówiona jest terminologia związana z testamenti factio, jej uwarunkowania, a także wpływ na nią zdolności prawnej i zdolności do czynności prawnych). W drugiej części rozdziału autor wymienia i omawia osoby uprawnione do sporządzenia ważnego testamentu. Jego zdaniem na osobne omówienie zasługują wolnourodzeni własnego prawa, wolnourodzeni podlegli władzy ojcowskiej oraz wyzwoleńcy.

W rozdziale III, „Figura prawna testatora w świetle uznanych w prawie justyniańskim czynników znoszących lub ograniczających testamenti factio activa", autor wymienia osoby, które zdolności do sporządzania testamentu nie miały wcale lub im ją odebrano. Są to niewolnicy, cudzoziemcy, osoby podległe władzy ojcowskiej, skazani na deportację, śmierć lub pracę w kopalniach, niedojrzali, chorzy umysłowo, marnotrawcy, głusi lub niemi, a także heretycy lub apostaci. Prócz ogólnej zasady autor podaje także sytuacje, w których wyjątkowo takim osobom testamenti factio activa przysługiwała. Dotyczyło to na przykład osób alieni iuris, które dysponować mogły peculium castrense lub quasi-castrense.

W rozdziale IV, „Kompleksowe spojrzenie na formę testamentu i podziały testamentów w świetle źródeł prawa justyniańskiego”, autor wskazuje kolejno na wieloznaczność terminu „forma”, pojęcie formy testamentu, formalne wymogi ważności testamentu, a także podaje podstawowe podziały testamentów ze względu na formalne uwarunkowania podmiotowe i przedmiotowe. Wedle tego kryterium wyróżnia testamenty osób cywilnych oraz testamenty żołnierzy, testamenty pisemne i testamenty ustne, testamenty z udziałem świadków zwykłych i testamenty z udziałem świadków pełniących funkcje publiczne, a także testamenty z zachowaniem wszystkich formalnych wymogów prawa (testamenta perfecta) i testamenty bez zachowania wszystkich formalnych wymogów prawa (testamenta imperfecta).

Rozdział V, zatytułowany „Zwyczajne formy testamentu uznane w prawie justyniańskim", zawiera uwagi na temat sposobu spisania testamentu, wymogu unitas actus, konieczności złożenia podpisów oraz obecności świadków. Pierwszą sekcję tego rozdziału kończy definicja zwyczajnej formy testamentu. Następnie autor przechodzi do omówienia wyróżnianych przez dotychczasową naukę prawa rzymskiego rodzajów 
takich testamentów. Są to: zwyczajny testament ustny (testamentum per nuncupationem) oraz testament pisemny.

Kolejny, VI rozdział poświęcony jest testamentowi żołnierskiemu w świetle ustawodawstwa Justyniana. Autor omawia w nim następujące zagadnienia: podmiot czynny, czyli uprawniony do sporządzenia testamentum militis, sposób jego sporządzenia, wymóg obecności świadków, kwestię konieczności zachowania unitas actus, a także zasady, wedle których mogło nastąpić uznanie testamentu sporządzonego na podstawie prawa powszechnego za żołnierski. Następną częścią tego rozdziału jest definicja testamentu żołnierskiego. Dalszą część stanowią przemyślenia na temat testamentu na wzór żołnierskiego (testamentum quasi militis).

W rozdziale VII autor wymienia szczególne formy testamentu w prawie justyniańskim. Zaliczył do nich testament dotkniętego chorobą zakaźną, testament na rzecz kościołów lub dzieł pobożnych, testament rodzica na rzecz swoich zstępnych, testament analfabety lub niemogącego się podpisać, testament niewidomego, testament głuchoniemego lub niemego, testament wiejski. W ramach omówienia poszczególnych form testamentu autor wyodrębnił mniejsze jednostki redakcyjne, w których opisał cechy wyróżniające daną formę testamentu, takie jak na przykład okoliczności warunkujące sporządzenie aktu w tej formie, specyfikę testatora czy dziedzica, wymogi dotyczące liczby wymaganych świadków, konieczność własnoręcznego spisania testamentu czy też umieszczenia daty jego sporządzenia.

Ostatni, VIII rozdział to „Aprobata prawa justyniańskiego dla testamentów z udziałem świadków pełniących funkcje publiczne”. Wskazane są w nim następujące odmiany testamentów: testament $\mathrm{z}$ udziałem cesarza (testamentum principi oblatum) oraz testament $\mathrm{z}$ udziałem sędziego lub urzędnika miejskiego (testamentum apud acta).

Jak wspomniałam, książka Sławomira Kursy zapowiada się ciekawie. Autor nie ustrzegł się jednak różnorakich usterek. Już tytuł monografii budzi wątpliwości. Określenie „w rzymskim prawie justyniańskim” stanowi raczej superfluum; w innych niż rzymskie prawach okres justyniański nie jest wyróżniany. Lepiej chyba brzmiałoby po prostu Testator i formy testamentu $w$ prawie justyniańskim. 
Jak wskazuje sam autor we wstępie, w pracy omawiane są nie tylko źródła prawa tworzone za czasów cesarza Justyniana, lecz także inne źródła prawa klasycznego i poklasycznego zawarte w kodyfikacji justyniańskiej. Należy tutaj zwrócić uwagę na budzącą wciąż kontrowersję kwestię badania interpolacji. Oczywiście te teksty, w które kompilatorzy ingerowali, a więc teksty interpolowane, to niewątpliwie prawo justyniańskie. Czy natomiast można traktować jako takie teksty autentyczne? Czy jest to prawo justyniańskie, bo Justynian przejął je do swojej kodyfikacji, czy też jest to po prostu prawo (nadal) obowiązujące w czasach Justyniana? Jest to o tyle istotne, że autor wskazał we wstępie na chęć rozgraniczenia utrzymanej przez Justyniana tradycji prawnej od innowacji przez niego wprowadzonych. Niepokoi także chęć przeprowadzenia przez autora wykładni systemowej tekstów źródłowych podczas ich egzegezy. Badacze prawa rzymskiego wciąż mają wątpliwości, czy prawo rzymskie było systemem prawnym w dzisiejszym znaczeniu. Zatem możliwość przeprowadzenia wykładni systemowej jego źródeł może się okazać w zasadzie niemożliwa.

Pewne zastrzeżenia wywołuje także sformułowanie dwóch hipotez (czy właściwie: tez) badawczych umieszczonych przez autora we wstępie. Taki zabieg może być uznany za dopuszczalny i zrozumiały. Autor postanowił sprawdzić dwa konkurencyjne (nie alternatywne - oprócz podanych możliwości, jest jeszcze trzecia - „w prawie justyniańskim wartość swobody testowania była mniej ceniona niż bezpieczeństwo obrotu prawnego w zakresie testamentów”) stwierdzenia. Wolno mu było zatem postawić przypuszczenia, które wzajemnie się wykluczają, aby w ten sposób sprecyzować kierunek badań i jednocześnie uniknąć zarzutu o pisanie pracy „pod tezę”. Teza to wszak problem badawczy, pewne założenie, którego prawdopodobieństwo wymaga sprawdzenia i udowodnienia. W tym przypadku wystarczyłoby jednak sprawdzić jedną z postawionych tez, bowiem prawdziwość jednej automatycznie falsyfikuje drugą (a także trzecią) możliwość. Postawienie dwóch tez nie było zatem konieczne.

Rozdział I książki to pierwsze miejsce, w którym autor tak wyraźnie odwołał się do terminologii współczesnego prawoznawstwa. Nie do końca jestem przekonana co do zasadności tego zabiegu w monografii 
poświęconej prawu rzymskiemu, w którym przecież nie ufano definicjom (por. tekst autorstwa Jawolenusa zawarty w D. 50,17,202: Omnis definitio in iure civili periculosa est: parum est enim, ut non subverti posset. - wszelka definicja w prawie cywilnym jest niebezpieczna, jest bowiem rzadkie, żeby nie dało się jej obalić). Wątpliwości budzi zwłaszcza, zapowiedziany jeszcze we Wstępie, podział definicji na słowne, źródłowe i doktrynalne.

W rozdziale analizującym kwestie terminologiczne poważnym niedociągnięciem autora wydaje się zupełne pominięcie uznanych wydawnictw słownikowych, w tym tych poświęconych łacińskiej terminologii. Są to przykładowo A. Walde, Lateinisches Etymologisches Wörterbuch ${ }^{3}$, Heidelberg 1954; A. Ernout, A. Meillet, Dictionnaire étymologique de la langue latine. Histoire des mots ${ }^{4}$, Paris 2001; Oxford Latin Dictionary, red. P.G.W. Glare, Oxford 2007, czy choćby jedyne tak kompleksowe opracowanie w języku polskim: J. Sondel, Słownik łacińsko-polski dla prawników i historyków², Kraków 2006.

Dziwi także nieuzasadnione układem przedmiotowym zaburzenie chronologii w tym rozdziale - wszak kwestie terminologiczne warto omówić wedle kolejności, w jakiej wyjaśniano opisywane przez autora pojęcia. Nie jestem także pewna, czy w każdym przypadku źródła pojustyniańskie mogą służyć do ustalenia znaczenia terminu w prawie justyniańskim.

Zastosowane w rozdziale II określenie „figura testatora”, przewijające się zresztą w całej książce, wydaje się niepotrzebną kalką z języka włoskiego. Dlaczego nie pisać po prostu o „osobie testatora”, czy wręcz o „testatorze”? W tym rozdziale znaleźć można także inne nieścisłości. Znów występuje zaburzenie chronologii - powoływany jest Gaius, potem Instytucje justyniańskie, następnie teksty jurystów klasycznych zawarte w Digestach. Oczywiste jest, że odstępstwa od chronologii bywają uzasadnione i to nawet często, ale zachowanie jej w części poświęconej wyjaśnieniu pojęcia ułatwiłoby prześledzenie jego ewolucji.

Użyte na s. 42 i kolejnej sformułowania stwarzają błędne wrażenie, że autor zrównuje testamenti factio activa ze zdolnością prawną - podaje bowiem jedynie czynniki warunkujące zdolność prawną, jako te określające zdolność do sporządzenia testamentu. Wrażenie jest błędne, 
gdyż z dalszej części tekstu wynika, że tak nie jest. Autor słusznie, podążając za stwierdzeniem Papiniana, zalicza testamenti factio do materii publicznoprawnej i przekonująco tej słuszności dowodzi. W żadnym wypadku nie nazwałabym jednak zdolności do sporządzania testamentu instytucją prawa publicznego (s. 43).

Z kolei na s. 50 autor przyznał status obywatela rzymskiego „wszystkim wolnourodzonym, a od czasów Justyniana także wszystkim wyzwoleńcom”. Nie jest to sformułowanie do końca szczęśliwe, wskazuje bowiem na to, że obywatelstwo rzymskie mogła mieć każda wolnourodzona osoba, niezależnie od tego, czy spełniała wymogi związane z uzyskaniem obywatelstwa, czy też nie. Jakkolwiek w czasach Justyniana Cesarstwo Rzymskie obejmowało bardzo duże terytorium, a wszystkie wolne osoby Cesarstwo zamieszkujące od wydania constitutio Antoniniana miały obywatelstwo rzymskie, to jednak nie stanowiło ono jedynego ośrodka cywilizacji w tamtych czasach. Zbytnim uogólnieniem jest także stwierdzenie, że: „Status osoby sui iuris przysługiwał zarówno pater familias, jak i mater familias", takie bowiem stwierdzenie implikuje wniosek, że każda mater familias była osobą sui iuris. Jak wynika z tekstów źródłowych cytowanych w artykule W. Wołodkiewicza (Materfamilias, «Czasopismo Prawno-Historyczne»16.1/1964, s. 103-142), na który zresztą autor powołuje się w innych miejscach pracy, ten zaszczytny tytuł mógł dotyczyć również kobiet pozostających wciąż pod władzą swojego ojca, a także kobiet wchodzących pod władzę męża. W czasach Justyniana ta ostatnia instytucja co prawda już nie istniała, jednak rozważania autora w tym zakresie nie są ograniczone do tego okresu.

Na s. 54 autor cytuje (wedle swoich słów) „klasycznych prawników Ulpiana i Paulusa”. Podane przez niego teksty pochodzą jednak z dwóch zbiorów: Tituli ex corpore Ulpiani oraz Pauli Sententiae. Autorstwo żadnego z tych wyborów nie jest ustalone z całą pewnością, powszechnie jednak uważa się, że nie są to dzieła jurystów, których nazwiska pojawiają się w tytułach.

Jak się wydaje, uogólnienia stanowią piętę achillesową autora, czasem negatywnie wpływając na odbiór jego pracy.

Na s. 66 pojawia się zdanie „(...) wypowiedź Juliana z księgi 39 Digesta nie pozostawia wątpliwości, że ojciec rodziny (pater familias) był 
podmiotem testamenti factio activa". Autor jakby zapomniał, że przed chwilą (s. 61) sam słusznie zauważył, że testament osoby chorej psychicznie był zawsze nieważny, a choroba taka nie pozbawiała nikogo funkcji zwierzchnika familijnego. Poza tym przytoczony przez niego na poparcie tego stwierdzenia tekst ([...] quia pater familias, qui testamenti factionem habet [...]) po pierwsze jest wyrwany z kontekstu (mniejsza o to, ten niewiele zmienia), a po drugie, tłumaczony być powinien „ponieważ zwierzchnik rodziny, KTÓRY ma zdolność sporządzania testamentu". W żadnym razie Julian nie twierdził, że każdy pater familias dysponował testamenti factio activa.

Na s. 81 autor pisze, że „W rozdziale wykazano, że zdolność do sporządzenia testamentu (...) obejmowała także uprawnienie do powołania świadków testamentowych". Na początku tego rozdziału (s. 48) wykluczył jednak konieczność wykazywania powyższej tezy, skoro bardzo wyraźnie wskazał na udowodnienie jej przez innego badacza.

Po przeczytaniu rozdziału III wątpliwości budzi wyodrębnienie drugiej części rozdziału II (tej dotyczącej osób mających testamenti factio activa) - wydaje się, że lepsze na nią miejsce byłoby tutaj, tym bardziej że zawarte w poszczególnych punktach tego podrozdziału informacje pojawiły się również w części poświęconej zdolności do sporządzania testamentu. Także i w tym rozdziale autor nie ustrzegł się niedociągnięć. Na pierwszej stronie (s. 83) pisze: „(..) obywatele alieni iuris mogli zaś testować w zakresie posiadanego peculium castrense albo peculium quasi-castrense. Zdarzało się jednak, że osoby te traciły zdolność prawną (...)”. Jak osoba alieni iuris mogła utracić zdolność prawną, skoro już jej nie miała? Na pierwszy rzut oka to konstrukcja akapitu wydaje się nieprzemyślana, z jego początku wnioskować można bowiem, że autor miał na myśli utratę zdolności prawnej przez osoby sui iuris, ale w końcówce mamy „a w przypadku osób sui iuris także”, co niestety wskazuje na rozważania na temat utraty zdolności prawnej również przez osoby jej niemające.

Wymieniając na s. 89 sposoby wejścia pod władzę ojcowską, autor $\mathrm{z}$ niewiadomych powodów pominął adopcję. Nie powodowała ona co prawda zmiany status familiae adoptowanego, jako że dotyczyła osób 
alieni iuris, natomiast znów zbytnia generalizacja na początku akapitu niepotrzebnie powoduje wrażenie błędu autora.

Na s. 100 autor, pisząc o marnotrawcy, wskazuje: „mógł natomiast dokonywać czynności przysparzających, np. przyjąć spadek”. Zapomina jakby, że masa spadkowa mogła obejmować także długi, których przyjęcie czynnością przysparzającą zdecydowanie nie jest, nie powiększa bowiem majątku. Na poparcie tezy o odebraniu marnotrawcy zdolności do sporządzania testamentu na skutek wydania interdyktu autor powołuje $\mathrm{z}$ kolei fragment D. 28,1,18 pr. (Is cui lege bonis interdictum est testamentum facere non potest et, si fecerit, ipso iure non valet: quod tamen interdictione vetustius habuerit testamentum, hoc valebit. merito ergo nec testis ad testamentum adhiberi poterit, cum neque testamenti factionem habeat.) Tymczasem wedle tekstu Digestów zakaz sporządzania testamentu dotyczy tylko tego marnotrawcy, który został pozbawiony prawa do rozporządzania majątkiem ustawą (lege), zaś użyte w tekście słowo interdictione nie oznacza interdyktu, lecz po prostu zakaz. W prawie rzymskim znany był sposób ustanowienia cura prodigi przez pretora (cura dativa), ale to nie o nim jest ten tekst. Początkowo pretor ustanawiał kuratora dla marnotrawcy dekretem, deklaratywnie na podstawie ius civile, po przeprowadzeniu cognitio. Interdykt natomiast był oparty na imperium pretora i tworzył nową sytuację prawną, niekoniecznie przewidzianą przez ius civile. Nie należy zatem mylić tych dwóch porządków.

Ciekawe są przeprowadzone w rozdziale $\mathrm{V}$ wywody na temat problematyki pisemnego testamentu cywilnego spełniającego wymogi prawa pretorskiego. Autor dochodzi do uzasadnionego wniosku, że taka forma testamentu nie funkcjonowała jako odrębna w prawie justyniańskim.

W rozdziale VI największe zastrzeżenia budzą rozważania na s. 210-211. Interpretując tekst D. 29,1,15,2, autor pisze: „Dodane przez kompilatorów zdanie si militis voluntas contraria non sit suponuje, że żołnierz musiał zamanifestować wolę, by jego testament sprzed służby wojskowej pozostał nienaruszony w swojej treści i jako taki stał się testamentem żołnierskim". Taki wniosek nie wydaje się w żaden sposób wynikać ani $\mathrm{z}$ tekstu źródłowego (Testamentum ante militiam factum a milite, si in militia decesserit, iure militari valere, si militis voluntas contraria non sit, 
divus Pius rescripsit.), ani z faktu jego przypuszczalnej interpolacji, ani z parafrazy tekstu dokonanej wcześniej przez autora. Tekst oznacza po prostu, że testament zwykły żołnierza staje się testamentem żołnierskim, jeśli żołnierz nie wyraziłby woli przeciwnej i nie ma potrzeby interpretowania go przez pryzmat podwójnego przeczenia, przez co wyciąga się wniosek wbrew brzmieniu tekstu. Takiej interpretacji nie uzasadnia także sprzeczność między tym tekstem, a D. 29,1,20,1, ponieważ są to teksty różnych jurystów (Juliana i Ulpiana), a dodatkowo Ulpian relacjonuje treść reskryptu cesarskiego.

Na s. 222 (rozdział VII) autor przeprowadza krótkie, ale bardzo ciekawe rozważania na temat różnic w zachowanych wersjach Kodeksu justyniańskiego. Ma to bowiem znaczenie dla tematyki testamentu osoby dotkniętej chorobą zakaźną. Także podane na stronach wcześniejszych uzasadnienie przyjęcia takiej nazwy owego testamentu (zamiast przyjętej do tej pory, nieuzasadnionej źródłowo nazwy testament pestis tempore) zasługuje na uznanie.

Na ss. 227-240 autor opisuje testament na rzecz kościołów lub dzieł pobożnych. Umieścił ten fragment w rozdziale dotyczącym szczególnych form testamentu, stwierdzając, że testament taki w świetle prawa justyniańskiego nie stanowił szczególnej formy, był nią w świetle prawa kanonicznego. Potrzeba jego wyróżniania istniałaby wtedy, gdyby nie był ważny w świetle prawa cywilnego. Taki testament był ważny na gruncie prawa kanonicznego, jeśli w jego sporządzaniu uczestniczyło co najmniej dwóch świadków.

Na s. 248 (i wcześniejszych) brakuje uzasadnienia źródłowego dość ważnego ustalenia, że: „Złagodzona forma testamentum parentis inter liberos wyrażała się w tym, że nie wymagał on do swej ważności udziału świadków".

W rozdziale VIII autor w przekonujący sposób weryfikuje dotychczasowe stanowisko nauki prawa rzymskiego w kwestii istnienia testamentów publicznych. Jego zdaniem, po pierwsze, każdy testament jako czynność prawna ma charakter prywatny. Po drugie zaś taka nazwa nie ma uzasadnienia źródłowego - proponuje zatem zastąpić dotychczasowy podział testamentów na prywatne i publiczne podziałem na te 
z udziałem świadków zwykłych i te z udziałem świadków pełniących funkcje publiczne.

$\mathrm{Na}$ koniec chciałabym powrócić do kwestii stanowiących w moim odczuciu uchybienia ciążące na całościowym odbiorze książki Sławomira Kursy. Przede wszystkim jest to, wspomniane już na początku, posługiwanie się terminologią współczesnego prawoznawstwa. Dla przykładu, autor pisze o przepisach prawa (s. 31), systemie prawa rzymskiego (s. 35), formalnych uwarunkowaniach podmiotowych i przedmiotowych (s. 128), organach władzy publicznej czy decyzji administracyjnej (s. 136), normie i jej dyspozycji (s. 156) itp. Jest to niewątpliwie zabieg mający przybliżyć tematykę pracy prawnikom zajmującym się prawem współczesnym, jednak poprawność korzystania $\mathrm{z}$ tych pojęć w monografii poświęconej prawu rzymskiemu budzi moje wątpliwości.

W pracy znajdują się także różnorakie niefortunne sformułowania, typu: „osobista czynność prawna” (s. 31), „rozpoznawanie testamentu” (s. 41), „prawidłowo wyzwolony niewolnik” (s. 76) - autorowi ewidentnie chodzi tu o niewolnika wyzwolonego formalnie, „czynniki uniezdatniające” do sporządzenia testamentu (s. 83), „uprzyczynowienie” (s. 109), „testament bezwartościowy” (s. 126), „choroba niezależna od woli” (s. 221) czy wreszcie „naród rzymski” (s. 116). Sprawiają one wrażenie niepotrzebnego komplikowania stosowanej terminologii, czy też, jak ostatni termin, są po prostu błędne.

Treść niektórych tekstów źródłowych przytaczana jest kilkukrotnie w wersji oryginalnej, raz w treści głównej, raz w przypisach. Szczególnie widoczne jest to w przypadku tekstu D. 37,11,1,8, który został poszatkowany i można odnieść wrażenie, że w pracy pojawia się co chwila (rozdziały II i III). Dziwi też omawianie jednakowo brzmiących tekstów (I. 2,12,5 i D. 28,1,8 pr.) w dwóch różnych miejscach pracy, bez unaocznienia ich identyczności (s. 57 i 85). Z kolei na s. 257 autor porównuje dwa teksty źródłowe (NTh. 16,3 oraz C. 6,23,21,1), przy czym przytacza tylko jeden $z$ nich. Pisze co prawda, że interesujące go zdanie jest w obu przypadkach identyczne, wcześniej jednak tożsame brzmienie tekstów nie przeszkadzało autorowi przytaczać obu z nich (co zresztą jest zabiegiem, który pozwala czytelnikowi na porównanie i samodzielne stwierdzenie tożsamości tekstów bez sięgania do innych wydawnictw). 
W książce przewijają się także inne niedociągnięcia. Część z nich wskazałam przy omawianiu kolejnych rozdziałów. Są jednak takie, które nazwałabym wątpliwościami natury ogólnej. Jako romanistkę razi mnie fakt wykorzystania jako podstawy wyciągania wniosków wersji łacińskich tekstów, których oryginał powstał w języku greckim. Dotyczy to przede wszystkim konstytucji Justyniana zebranych w Nowelach oraz interpretacji zawartych w Bazylikach. Tak, istnieją łacińskie tłumaczenia tych tekstów, jednak nie powinny być one w moim odczuciu podstawą do prowadzenia badań nad prawem justyniańskim; powinny być wykorzystywane jedynie pomocniczo. Każde tłumaczenie jest już bowiem interpretacją tekstu, dokonaną przez tłumacza. W związku z tym dociekania oparte na tłumaczeniu mogą nie uwzględniać niektórych aspektów tekstu oryginalnego. A przez to analiza tekstu nie może być pełna.

Niejednokrotnie odniosłam także wrażenie, że autor utożsamia pojęcia ważności i skuteczności testamentu - na przykład na s. 195, kiedy pisze o odebraniu skazanemu na śmierć żołnierzowi testamenti factio activa i o tym, że „wcześniej sporządzony przez niego testament stawał się bezskuteczny”. Tymczasem, na s. 59 pisał, że „we wszystkich innych przypadkach [poza fictio legis Corneliae, postliminium i ułaskawieniem przez cesarza], gdy testator doznawał capitis deminutio maxima, sporządzony przez niego testament stawał się z mocy prawa nieważny". Oczywiście, nieważny testament nie wywiera skutków prawnych, ale nie należy stwarzać wrażenia, że nieważność i nieskuteczność testamentu są tym samym. Podobnie jest w przypadku wywodów na s. 254. Autor przekazuje poglądy innego badacza, wydaje się jednak, że błąd jest jego.

$\mathrm{Na}$ koniec warto zauważyć, że odniesienia autora co do konkurencyjnych tez postawionych we wstępie (dla przypomnienia: „w prawie justyniańskim wartość swobody testowania była wyżej ceniona niż bezpieczeństwo obrotu prawnego w zakresie testamentów” oraz „w prawie tym możemy mówić o zrównoważonym traktowaniu wymienionych wartości”) pojawiające się we wnioskach z rozdziałów wydają się za każdym razem sztucznie doklejone, bowiem nic wcześniej w rozdziałach nie sugeruje rozważań w tym zakresie. 
Najistotniejszy problem tkwi jednak w czym innym, to jest w zakresie badawczym postawionych przez autora tez. Nie jestem przekonana, czy przeprowadzone badania mogą jednoznacznie wykluczyć jedną z nich. Tezy nie brzmią bowiem „biorąc pod uwagę osobę testatora i formy testamentu, itd.”. Są bardziej ogólne. Nie jest to kwestia, którą można rozstrzygnąć, przyglądając się wyłącznie regulacjom dotyczącym możliwości sporządzenia przez daną osobę testamentu i tego, jakich wymogów należy dochować, żeby testament był ważny. Należałoby rozpatrzyć jeszcze, na przykład, treść rozporządzeń testamentowych czy też przypadki zmiany lub odwołania testamentu.

Popełnianie błędów i dopuszczanie się nieścisłości są, niestety, związane z działalnością badacza każdej dziedziny nauki. Pozostaje tylko mieć nadzieję, że na tych błędach będziemy się uczyć.

Elżbieta Loska*

* Uniwersytet Kardynała Stefana Wyszyńskiego w Warszawie. 